\title{
Total Body Water Content of Neonates with Obstruction of Alimentary Tract
}

\author{
STAVROS TSINGOGLOU, HARRIETT PHILLIPS, and ANDREW W. WILKINSON \\ From the Institute of Child Health, University of London; and The Hospital for Sick Children, Great Ormond Street, \\ London
}

\begin{abstract}
Tsingoglou, S., Phillips, H., and Wilkinson, A. W. (1972). Archives of Disease in Childhood, 47, 941. Total body water content of neonates with obstruction of alimentary tract. The total body water content was measured by the deuterium oxide dilution method in 55 neonates admitted to hospital for surgical treatment within 90 hours of birth. The mean total body water of the whole group was $77.03 \pm 0.62$ (SEM) \% of the body weight (range 67.4 to $88.6 \%$ ), or $1.974 \pm 0.005$ (SEM) litres (range 1.010 to 2.830 litres). Over a range of body weights from 1.160 to $3.851 \mathrm{~kg}$, total body water content expressed as a percentage of body weight decreased by $5 \%$ per $\mathrm{kg}$ rise in body weight, but when expressed as litres per $\mathrm{kg}$ body weight it increased by $737 \mathrm{ml}$ for each rise of $1 \mathrm{~kg}$ in body weight. There was a small difference in water content between babies with obstruction of the alimentary tract and those with other nonobstructive lesions, which was not statistically significant.
\end{abstract}

It has been widely assumed that in neonates with congenital obstruction of the alimentary tract, vomiting and starvation result in gross disturbances of the volume and composition of body fluid which must be corrected before the obstruction is relieved by operation. Practical experience during the past 13 years in the treatment of more than 500 such neonates has shown that, unless the circulating blood volume is so reduced as to cause impaired peripheral capillary blood flow, the arbitrary preoperative replacement of such fluid losses with $0.9 \%$ or $0.18 \%$ saline is unnecessary. The only circumstances in which preoperative restoration of circulating blood volume is required are (1) when there has been sequestration or loss of whole blood, in a volvulus of the midgut or of a small intestinal atresia, or (2) when a baby with duodenal atresia has been allowed to continue to vomit and starve for 10 to 14 days. Disturbance of acid base equilibrium is uncommon in neonates with intestinal obstruction unless surgical relief of the obstruction is delayed beyond a week. A negative base excess of up to $15 \mathrm{mEq} /$ litre is a usual sequel of starvation for 3 or 4 days at any age and does not need to be corrected, since equilibrium is rapidly reestablished when the oral consumption of food begins. Even when there is a change in acidbase equilibrium of more than $15 \mathrm{mEq}$, treatment

Received 14 April 1972. immediately affects only the extracellular fluid component of the disturbance, which may be of acute benefit in babies with incipient cardiac failure; complete correction depends mainly on the homeostatic influence of the oral consumption of an adequate intake of milk.

The association of hydramnios with atresia of the oesophagus or duodenum may be the result of abnormal circulation of amniotic fluid between mother and child, and this has aroused the suspicion that the body composition and particularly the water content of the baby may also be altered. Up to $40 \%$ of babies with atresia of the oesophagus or duodenum are unusually small at birth, and some of them have severe associated anomalies in other systems. Postoperative complications are common and often severe and may interfere with feeding and cause large losses of intestinal secretion. The consequent need for repeated replacement of lost fluids by intravenous infusion, combined with starvation, leads to complicated disturbances of whole body composition, of which little is known except by analogy with the effects of tropical protein malnutrition (Garrow, Smith, and Ward, 1968).

It seemed, therefore, that the total body water content should be measured before operation in neonates with atresia of the oesophagus and duodenum, and in some other kinds of alimentary obstruc- 
tion, to find out whether their initial body water content was normal or not.

\section{Methods}

Heavy water $\left(\mathrm{D}_{2} \mathrm{O}\right) \mathbf{9 9} \cdot \mathbf{8} \%$ pure, pyrogen-free, and made isotonic with $0.85 \% \mathrm{NaCl}$ was injected into the muscles of the lateral aspect of the thigh in doses approximately $1.5 \mathrm{~g} / \mathrm{kg}$ body weight. The syringe was weighed to the nearest $\pm 0.0005 \mathrm{~g}$ before and after injection. 1 to $2 \mathrm{ml}$ venous blood was collected after equilibration for at least 2 hours, mean 2 hours 15 minutes (Faller et al., 1955). When estimations were repeated, a preliminary blank sample of blood was collected. Water was extracted from the whole blood by freeze-drying in a manifold closed vacuum system, 6 samples being treated simultaneously (Schloerb et al., 1950).

The $\mathrm{D}_{2} \mathrm{O}$ content of the extracted water was then measured on a Hilger and Watts $\mathrm{H} 900$ double-beamed absorption infrared spectrophotometer with an $\mathrm{NaCl}$ prism. The machine was modified to have a fixed slit width of $2 \cdot 0 \mathrm{~mm}$ at $3 \cdot 8 \mu$. Scanning was from $2880 \mathrm{~cm}^{-1}$ to $2400 \mathrm{~cm}^{-1}$ (with $\mathrm{D}_{2} \mathrm{O}$ wavelength at $2520 \mathrm{~cm}^{-1}$ ), using CaF2 windows and $0.2 \mathrm{~mm}$ cell spacers (Fydelor and Rawson, 1964). Samples of the distillate were equilibrated from 10 minutes at $25^{\circ} \mathrm{C}$ in a water bath. The samples were read at a $\times 5$ scale expansion. Each sample was read twice between two standards. Between each estimation the cell was washed and dried three times with acetone and nitrogen. Standard samples were prepared by adding known amounts of deuterium oxide to distilled water (Turner, Neely, and Hardy, 1960). Recoveries of $\mathrm{D}_{2} \mathrm{O}$ added to whole blood were $99.9 \% \pm 0.29 \%$ at $0.1 \% \mathrm{w} / \mathrm{w}$ $\mathrm{D}_{2} \mathrm{O}$ level, $99 \cdot 9 \% \pm 0.80 \%$ at $0.3 \% \mathrm{w} / \mathrm{w} \mathrm{D} \mathrm{D}_{2} \mathrm{O}$ level.

Total body water (TBW) was measured from 6 to 86 hours after birth in 55 neonates who had been referred for surgical treatment. In 39 neonates, congenital abnormalities of the gastrointestinal tract produced intestinal obstruction which required relief by operation (Table I); 16 other babies suffered from various disorders (Table II). None of these babies had been given any

TABLE I

Obstructive Group

\begin{tabular}{|c|c|c|c|c|c|c|c|}
\hline Diagnosis & $\begin{array}{l}\text { Case } \\
\text { No. }\end{array}$ & $\begin{array}{c}\text { Weight } \\
\text { (kg) }\end{array}$ & $\begin{array}{l}\text { Age } \\
(\mathbf{h r})\end{array}$ & $\begin{array}{l}\text { Weight } \\
\text { Loss } \\
(\%)\end{array}$ & $\begin{array}{c}\text { TBW } \\
\text { (\% of Body } \\
\text { Weight) }\end{array}$ & $\begin{array}{c}\text { TBW } \\
\text { (1.) }\end{array}$ & $\begin{array}{l}\text { Duration of } \\
\text { Pregnancy (wk) and } \\
\text { Method of Delivery }\end{array}$ \\
\hline $\begin{array}{l}\text { Oesophageal atresia } \\
\text { Oesophageal atresia } \\
\text { Oesophageal atresia } \\
\text { Oesophageal atresia } \\
\text { Oesophageal atresia } \\
\text { Oesophageal atresia } \\
\text { Oesophageal atresia } \\
\text { Oesophageal atresia } \\
\text { Oesophageal atresia } \\
\text { Oesophageal atresia } \\
\text { Oesophageal atresia } \\
\text { Oesophageal atresia } \\
\text { Oesophageal atresia } \\
\text { Tracheo-oesophageal fistula } \\
\text { Oesophageal and rectal atresias } \\
\text { Anorectal atresia } \\
\text { Anorectal atresia } \\
\text { Anorectal atresia } \\
\text { Anorectal atresia } \\
\text { Anorectal atresia } \\
\text { Anorectal atresia } \\
\text { Anorectal atresia } \\
\text { Anorectal atresia fistula } \\
\text { Rectovaginal fistula } \\
\text { Hirschsprung's disease } \\
\text { Hirschsprung's disease } \\
\text { Hirschsprung's disease } \\
\text { Hirschsprung's disease } \\
\text { Volvulus } \\
\text { Volvulus } \\
\text { Volvulus } \\
\text { Volvulus } \\
\text { Duodenal atresia } \\
\text { Deodenal atresia } \\
\text { Jejunal atresia } \\
\text { Jejunal atresia } \\
\text { Meconium ileus } \\
\text { Meconium ileus } \\
\text { Exomphalos with intestinal } \\
\text { obstruction }\end{array}$ & $\begin{array}{r}27 \\
28 \\
31 \\
33 \\
35 \\
44 \\
47 \\
57 \\
77 \\
90 \\
180 \\
118 \\
119 \\
104 \\
24 \\
8 \\
12 \\
13 \\
19 \\
51 \\
98 \\
120 \\
70 \\
81 \\
2 \\
9 \\
52 \\
64 \\
43 \\
61 \\
112 \\
106 \\
60 \\
114 \\
26 \\
54 \\
25 \\
116 \\
49 \\
\end{array}$ & $\begin{array}{l}2 \cdot 470 \\
2 \cdot 290 \\
1 \cdot 945 \\
1 \cdot 998 \\
2 \cdot 500 \\
2 \cdot 285 \\
2 \cdot 885 \\
2 \cdot 390 \\
2 \cdot 740 \\
2 \cdot 605 \\
1 \cdot 160 \\
2 \cdot 985 \\
2 \cdot 730 \\
2 \cdot 400 \\
3 \cdot 170 \\
3 \cdot 390 \\
2 \cdot 030 \\
3 \cdot 605 \\
2 \cdot 390 \\
3 \cdot 100 \\
2 \cdot 500 \\
2 \cdot 900 \\
2 \cdot 585 \\
2 \cdot 190 \\
2 \cdot 585 \\
3 \cdot 455 \\
2 \cdot 707 \\
2 \cdot 770 \\
2 \cdot 686 \\
2 \cdot 675 \\
2 \cdot 385 \\
3 \cdot 220 \\
2 \cdot 050 \\
1 \cdot 500 \\
2 \cdot 230 \\
1 \cdot 531 \\
1 \cdot 703 \\
2 \cdot 830 \\
2 \cdot 540 \\
2 \cdot 3\end{array}$ & $\begin{array}{r}6 \cdot 5 \\
30 \\
68 \\
19 \\
15 \\
53 \\
44 \\
45 \\
26 \\
12 \\
18 \\
32 \\
19 \\
85 \\
15 \\
13 \\
7 \\
36 \\
16 \\
17 \\
44 \\
24 \\
14 \\
9 \\
50 \\
53 \\
60 \\
64 \\
36 \\
65 \\
53 \\
72 \\
26 \\
51 \\
11 \\
28 \\
42 \\
24 \\
\end{array}$ & $\begin{array}{r}-2 \cdot 1 \\
-8 \cdot 2 \\
-10 \cdot 8 \\
-6 \cdot 0 \\
-0 \cdot 9 \\
-1 \cdot 5 \\
-6 \cdot 1 \\
-1 \cdot 2 \\
-4 \cdot 3 \\
-4 \cdot 8 \\
-5 \cdot 2 \\
-3 \cdot 9 \\
-7 \cdot 0 \\
-7 \cdot 6 \\
-2 \cdot 8 \\
-1 \cdot 6 \\
-10 \cdot 5 \\
-0 \cdot 8 \\
-0 \cdot 7 \\
-15 \cdot 2 \\
-4 \cdot 5 \\
-2 \cdot 5 \\
-\end{array}$ & $\begin{array}{l}80 \cdot 6 \\
78 \cdot 2 \\
77 \cdot 6 \\
79 \cdot 6 \\
78 \cdot 8 \\
76 \cdot 6 \\
73 \cdot 2 \\
76 \cdot 2 \\
73 \cdot 0 \\
75 \cdot 6 \\
87 \cdot 1 \\
73 \cdot 4 \\
76 \cdot 2 \\
77 \cdot 1 \\
69 \cdot 7 \\
73 \cdot 7 \\
73 \cdot 9 \\
72 \cdot 4 \\
76 \cdot 6 \\
73 \cdot 5 \\
76 \cdot 4 \\
77 \cdot 9 \\
77 \cdot 0 \\
78 \cdot 5 \\
72 \cdot 3 \\
69 \cdot 8 \\
77 \cdot 6 \\
82 \cdot 3 \\
74 \cdot 5 \\
71 \cdot 0 \\
69 \cdot 6 \\
75 \cdot 2 \\
78 \cdot 0 \\
82 \cdot 0 \\
80 \cdot 3 \\
82 \cdot 3 \\
83 \cdot 4 \\
77 \cdot 7\end{array}$ & $\begin{array}{l}1 \cdot 99 \\
1 \cdot 79 \\
1 \cdot 51 \\
1 \cdot 59 \\
1 \cdot 97 \\
1 \cdot 75 \\
1 \cdot 87 \\
1 \cdot 82 \\
2 \cdot 00 \\
1 \cdot 97 \\
1 \cdot 01 \\
2 \cdot 19 \\
2 \cdot 08 \\
1 \cdot 85 \\
2 \cdot 21 \\
2 \cdot 50 \\
1 \cdot 50 \\
2 \cdot 61 \\
1 \cdot 83 \\
2 \cdot 28 \\
1 \cdot 91 \\
2 \cdot 26 \\
1 \cdot 99 \\
1 \cdot 72 \\
1 \cdot 87 \\
2 \cdot 41 \\
2 \cdot 10 \\
2 \cdot 28 \\
2 \cdot 00 \\
1 \cdot 90 \\
1 \cdot 66 \\
2 \cdot 42 \\
1 \cdot 60 \\
1 \cdot 23 \\
1 \cdot 79 \\
1 \cdot 26 \\
1 \cdot 42 \\
2 \cdot 20 \\
2 \cdot 03 \\
2.03\end{array}$ & $\begin{array}{l}\text { Twin } \\
\\
36 \\
36 \\
35 \text { Twin } 2 \\
41 \\
\text { Term } \\
\text { Term } \\
34 \\
42 \\
37 \text { Caesarean } \\
\text { Caesarean } \\
3 \\
40 \\
41 \\
34 \\
\text { Term } \\
40 \\
\text { Term } \\
36 \\
\text { Term } \\
39 \\
33 \\
36 \text { Twin } 2 \\
33 \cdot 5 \\
38 \text { Twin } 2 \\
\\
31 \\
36\end{array}$ \\
\hline
\end{tabular}


TABLE II

Nonobstructive Group

\begin{tabular}{|c|c|c|c|c|c|c|c|}
\hline Diagnosis & $\begin{array}{l}\text { Case } \\
\text { No. }\end{array}$ & $\begin{array}{l}\text { Weight } \\
\text { (kg) }\end{array}$ & $\begin{array}{l}\text { Age } \\
\text { (hr) }\end{array}$ & $\begin{array}{l}\text { Weight } \\
\text { Loss } \\
(\%)\end{array}$ & $\begin{array}{l}\text { TBW } \\
\text { (\% of Body } \\
\text { Weight) }\end{array}$ & $\begin{array}{c}\text { TBW } \\
\text { (1.) }\end{array}$ & $\begin{array}{l}\text { Duration of } \\
\text { Pregnancy (wk) and } \\
\text { Method of Delivery }\end{array}$ \\
\hline $\begin{array}{l}\text { Retention of urine } \\
\text { Urinary obstruction } \\
\text { Hydronephrosis } \\
\text { Vesicointestinal fissure } \\
\text { Vesicointestinal fissure } \\
\text { Meconium plug } \\
\text { Pseudo-obstruction } \\
\text { Pseudo-obstruction } \\
\text { Pseudo-obstruction } \\
\text { Pseudo-obstruction, sclerema } \\
\text { Pseudo-obstruction, sclerema } \\
\text { Cleft lip and palate } \\
\text { Cleft lip and palate } \\
\text { Sacrococcygeal teratoma } \\
\text { Exomphalos } \\
\text { Tracheo-oesophageal fistula }\end{array}$ & $\begin{array}{r}11 \\
20 \\
62 \\
111 \\
113 \\
95 \\
36 \\
59 \\
78 \\
3 \\
107 \\
40 \\
117 \\
110 \\
75 \\
34\end{array}$ & $\begin{array}{l}3 \cdot 560 \\
3 \cdot 851 \\
3 \cdot 216 \\
2 \cdot 225 \\
2 \cdot 583 \\
2 \cdot 097 \\
3 \cdot 475 \\
1 \cdot 332 \\
2 \cdot 235 \\
1 \cdot 600 \\
2 \cdot 400 \\
2 \cdot 941 \\
3 \cdot 160 \\
3 \cdot 690 \\
3 \cdot 692 \\
2 \cdot 509\end{array}$ & $\begin{array}{r}53 \\
72 \\
16 \\
7 \\
34 \\
42 \\
40 \\
44 \\
48 \\
63 \\
58 \\
15 \\
50 \\
22 \\
12 \\
30\end{array}$ & $\begin{array}{l}-1 \cdot 9 \\
+7 \cdot 4 \\
-1 \cdot 9 \\
+11 \cdot 4 \\
-9 \cdot 0 \\
-6 \cdot 1 \\
-4 \cdot 1 \\
-6 \cdot 1 \\
-4 \cdot 4 \\
-5 \cdot 4 \\
+0 \cdot 7 \\
-5 \cdot 4 \\
-6 \cdot 3 \\
-4 \cdot 8\end{array}$ & $\begin{array}{l}67 \cdot 4 \\
70 \cdot 1 \\
76 \cdot 5 \\
78 \cdot 7 \\
79 \cdot 8 \\
83 \cdot 0 \\
77 \cdot 1 \\
88 \cdot 6 \\
85 \cdot 9 \\
86 \cdot 3 \\
75 \cdot 8 \\
78 \cdot 9 \\
70 \cdot 3 \\
76 \cdot 7 \\
75 \cdot 3 \\
78 \cdot 5\end{array}$ & $\begin{array}{l}2 \cdot 40 \\
2 \cdot 70 \\
2 \cdot 46 \\
1 \cdot 75 \\
2 \cdot 06 \\
1 \cdot 74 \\
2 \cdot 68 \\
1 \cdot 18 \\
1 \cdot 92 \\
1 \cdot 38 \\
1 \cdot 82 \\
2 \cdot 32 \\
2 \cdot 22 \\
2 \cdot 83 \\
2 \cdot 78 \\
1 \cdot 97\end{array}$ & $\begin{array}{l}\text { Term } \\
\text { Term } \\
33 \\
\text { Caesarean } \\
42 \\
35 \text { Caesarean } \\
34-36 \\
37 \\
\text { Term } \\
\text { Term } \\
37 \\
\text { Term } \\
40, \text { Caesarean } \\
33\end{array}$ \\
\hline
\end{tabular}

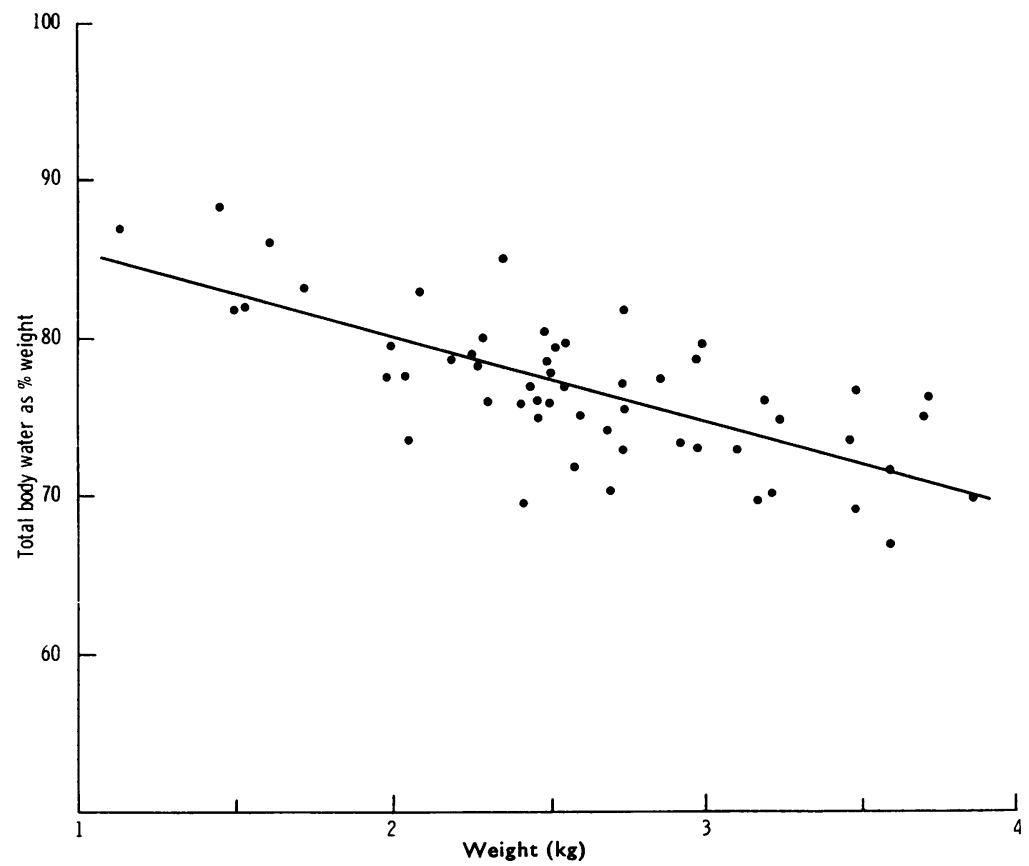

Fig. 1.-Total body water as percentage of body weight related to body weight. $\quad r=0 \cdot 7089, P<0 \cdot 001$.

fluid by intravenous infusion before admission or body water estimation, 25 of them had no oral fluids either, and those who had drunk fluids had vomited most of what they had taken. TBW was measured soon after admission and before operation or treatment was started.

\section{Results}

The body weight of the 55 neonates on admission ranged from 1.160 to $3.551 \mathrm{~kg}$ (mean $2.588 \pm$ $0.003 \mathrm{~kg}$ ). Compared with their stated birthweight, some babies appeared to have lost up to $15 \cdot 2 \%$ of birthweight while others appeared to have gained up to $11 \cdot 4 \%$

The mean TBW of the whole group when expressed as a percentage of body weight was $77 \cdot 03 \% \pm 0.62 \%$ (SEM), range $67 \cdot 4$ to $88 \cdot 6$, and when expressed in litres was $1.974 \pm 4.055$ (SEM), range $1 \cdot 010$ to $2 \cdot 830$ litres.

When TBW was expressed as a percentage of body weight (or in $\mathrm{ml}$ per $\mathrm{kg}$ body weight) and was plotted against weight (Fig. 1), there was a 


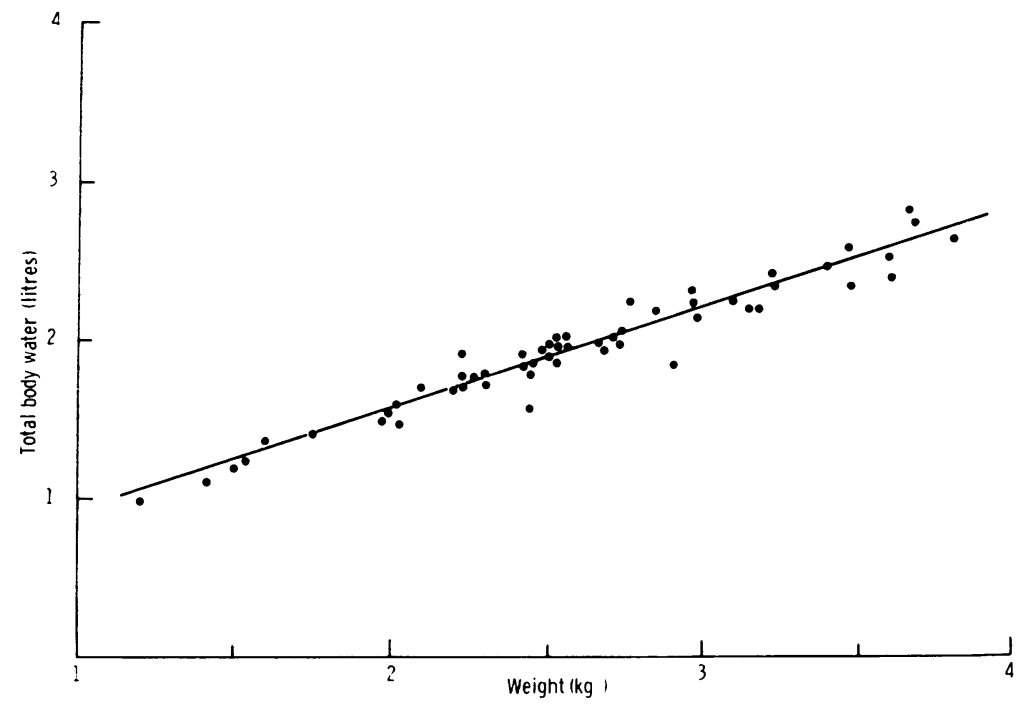

FIG. 2.-Total body water in litres related to body weight. $\quad r=0.9782, P<0.001$.

negative correlation coefficient of 0.7089 ( $\mathrm{P}<$ 0.001 ) and TBW as a percentage of body weight decreased by $5 \cdot 2 \%$ per $\mathrm{kg}$ over the range $1 \cdot 160$ to $3.851 \mathrm{~kg}$. When TBW in litres was plotted against weight (Fig. 2) there was a positive correlation of $0.9782(P<0.001)$ and total body water in litres increased by $736.6 \mathrm{ml} / \mathrm{kg}$ over the range $1 \cdot 160$ to $3 \cdot 851 \mathrm{~kg}$.

The detailed results of the two groups of babies with obstruction and the results of 16 other neonates are shown in Tables I and II. The results of further analysis of those babies in whom data were sufficiently complete is shown in Table III. Of the babies who were obstructed, 23 had not been given any fluid since birth and the remainder had vomited what had been given. Only 2 babies in the group without obstruction had not been given oral feeds since birth.

When TBW is expressed as a percentage of body weight or as litres of water against body weight, the difference in the correlation coefficients between the two groups of obstructed and nonobstructed babies is not significant. When body water is expressed as a percentage of body weight, this is a percentage of total water and total body solids, whereas when it is expressed as litres of water against weight, variation in body solids is not such a complicating factor.

\section{Discussion}

The deuterium oxide dilution method is probably the most accurate available method of measurement of total body water, since there is only a small amount of exchange of deuterium with labile hydrogen ions in proteins and carbohydrate, and only a small percentage of the water in bone and in the gastrointestinal secretion fails to reach equilibrium within 2 hours.

The mean value for TBW of $77.03 \%$ of body weight over a range of 1.332 to $3.692 \mathrm{~kg}$ in this whole series of 55 babies admitted for the treatment of various surgical emergencies compares well

TABLE III

Total Body Water (TBW) in Neonates with and without Intestinal Obstruction

\begin{tabular}{|c|c|c|c|c|c|c|c|c|}
\hline & $\begin{array}{c}\text { No. } \\
\text { of } \\
\text { Cases }\end{array}$ & $\begin{array}{c}\text { Mean Weight } \\
\text { at Time of } \\
\text { Estimation }\end{array}$ & Length & $\begin{array}{c}\text { Age } \\
(\mathbf{h r}) \\
\text { at } \begin{array}{l}\text { Time } \\
\text { of }\end{array} \\
\text { Estimation }\end{array}$ & TBW (ml/kg) & TBW (1.) & \begin{tabular}{|c|} 
Correlation \\
Coefficient \\
(<TBW as \% of \\
Body Weight \\
Against Weight)
\end{tabular} & $\begin{array}{l}\text { Correlation } \\
\text { Coefficient } \\
\text { (TBW in } \\
\text { litres against } \\
\text { Weight) }\end{array}$ \\
\hline $\begin{array}{l}\text { Obstructive } \\
\text { Nonobstructive }\end{array}$ & $\begin{array}{l}37 \\
13\end{array}$ & $\begin{array}{l}2 \cdot 469 \pm 0 \cdot 092 \\
2 \cdot 747 \pm 0 \cdot 199\end{array}$ & $\begin{array}{l}46 \cdot 92 \pm 0 \cdot 7 \\
47 \cdot 20 \pm 1 \cdot 35\end{array}$ & $\begin{array}{l}34 \cdot 91 \pm 3 \cdot 5 \\
39 \cdot 94 \pm 6 \cdot 3\end{array}$ & $\begin{array}{l}770 \cdot 1 \pm 7 \\
784 \cdot 5 \pm 1 \cdot 46\end{array}$ & $\begin{array}{l}1 \cdot 884 \pm 0 \cdot 060 \\
2 \cdot 126 \pm 0 \cdot 130\end{array}$ & $\begin{array}{l}-0.7528 \\
-0.7788\end{array}$ & $\begin{array}{l}0.9813 \\
0.9711\end{array}$ \\
\hline
\end{tabular}


with the $77 \cdot 0 \%$ over a range of 2.5 to $4.0 \mathrm{~kg}$ reported by Friis-Hansen (1965) and $80.0 \%$ over a range of $2 \cdot 001$ to $2 \cdot 435 \mathrm{~kg}$ (Clapp, Butterfield, and O'Brien, 1962), both also made with the $\mathrm{D}_{2} \mathrm{O}$ dilution method in normal babies. McLaurin (1966), who used antipyrine, found TBW was $71.5 \%$ of a mean body weight of $2 \cdot 46 \mathrm{~kg}$. FriisHansen (1969) found that the reported values obtained by the chemical analysis of whole cadavers ranged from $83.0 \%$ for a $1.5 \mathrm{~kg}$ body to $73.0 \%$ at $3.5 \mathrm{~kg}$. It is difficult to compare these more recent observations and our own with the results of earlier studies because of the lack of some of the essential data about weight and maturity at birth.

The good correlation between total body weight whether expressed as a percentage of body weight or in litres against body weight is similar to that found for total body water and extracellular fluid by Clapp et al. (1962), McLaurin (1966), and Cassady (1970), and suggests that there is not much disturbance of water content in the neonates with obstruction of the alimentary tract or other abnormalities which we have studied. On the whole the obstructed babies had lost more weight than the others, and this was probably due to the combination of starvation and fluid loss. Widdowson (1960) calculated that the starving neonate loses water and solids in about the same proportion as those in which they are present in the body at birth, and that in both premature and term babies the percentage composition of the body after two days of starvation is much the same as it was at birth. In the surgical management of neonates with oesophageal or duodenal atresia, it is of considerable importance to know that the total body water content is within the normal range for weight at birth and for up to 3 days thereafter, in spite of starvation and the lack of water intake. The maintenance of metabolism depends on the endogenous provision of energy derived from the oxidation of existing fat deposits, muscle protein, and the small quantity of available glycogen. The small indispensable requirements of water for insensible water loss and minimum urine formation can be provided from fat and protein catabolism and some loss of water from otherwise intact cells, consequent on the mobilization of potassium from them and its excretion in the urine. Little sodium is lost from the body except in vomited secretions; though maximal sodium conservation by the kidneys seems to depend on the provision of sufficient exogenous calories, very little is lost in the urine even by the starving neonate (Wilkinson, Stevens, and Hughes, 1962). Though the total water content of the starving neonate falls, it seems to do so in proportion to reduction in other measurable constituents unless there are large extrarenal losses of water and minerals. More information is clearly needed about the coincident changes in the body contents of sodium and potassium.

\section{REFERENCES}

Cassady, G. (1970). Bromide space studies in infants of low birth weight. Pediatric Research, 4, 14.

Clapp, W. M., Butterfield, L. J., and O'Brien, D. (1962). Body water compartments in the premature infant, with special reference to the effects of the respiratory distress syndrome and of maternal diabetes and toxemia. Pediatrics, 29, 883.

Faller, I. L., Petty, D., Last, J. H., Pascale, L. R., and Bond, E. E. (1955). A comparison of the deuterium oxide and antipyrine dilution methods for measuring total body water in normal and hydropic human subjects. Fournal of Laboratory and Clinical Medicine, 45, 748.

Friis-Hansen, B. J. (1965). Hydrometry of growth and aging. In Human Body Composition (Symposia of the Society for the Study of Human Biology, Vol. 7), p. 191. Ed. by J. Brožek. Pergamon Press, Oxford.

Friis-Hansen, B. J. (1969). Body composition during growth. In Nutrition in Pre-school and School Age. Symposium of the Swedish Nutrition Foundation, No. 7, p. 39. Ed. by G. Blix. Almqvist and Wiksell, Stockholm.

Fydelor, P. J., and Rawson, D. S. (1964). The measurement of deuterium in water near natural concentrations using a standard infra-red spectrometer. U.K. Atomic Energy Authority, AERE-R4785.

Garrow, J. S., Smith, R., and Ward, E. E. (1968). Electrolyte Metabolism in Severe Infantile Malnutrition. Pergamon Press, Oxford.

McLaurin, J. C. (1966). Changes in body water distribution during the first two weeks of life. Archives of Disease in Childhood, 41, 286.

Schloerb, P. R., Friis-Hansen, B. J., Edelman, I. S., Solomon, A. K., and Moore, F. D. (1950). The measurement of total body water in the human subject by deuterium oxide dilution. Fournal of Clinical Investigation, 29, 1296.

Turner, M. D., Neely, W. A., and Hardy, J. D. (1960). Rapid determination of deuterium oxide in biological fluids. Fournal of Applied Physiology, 15, 309.

Widdowson, E. iM. (1960). Chemical structure, functional integration, and renal regulation as factors in the physiology of the newborn. In Transactions of the Fourth Conference on Physiology of Prematurity, p. 97. Ed. by J. T. Lanman. Josiah Macy Foundation, New York.

Wilkinson, A. W., Stevens, L. H., and Hughes, E. A. (1962). Metabolic changes in the newborn. Lancet, 1, 983.

Correspondence to Professor A. W. Wilkinson, Institute of Child Health, 30 Guilford Street, London WC1N 1EH. 